\title{
Yaratıcı Drama Alanında Gavin Bolton'ın Drama Anlayışı
}

\author{
Asuman Özçelik Çetin ${ }^{1}$
}

\begin{abstract}
Ali Öztürk²
$\ddot{O}_{z e t}$

Bu araştırmada Gavin Bolton'a göre drama, eğitimde drama, eğitimde tiyatro, dramatik etkinlik, anlam ve drama, nesnel ve öznel anlam, dramanın amaç ve hedefleri, drama dersinin değerlendirilmesi, süreç içerisinde öğretmenin rolü, drama efsaneleri, dramada tiyatro ögeleri, anlam için dramanın özellikleri gibi kavramlar incelenmiş, Gavin Bolton'un biyagrafisine yer verilmiştir.
\end{abstract}

Anahtar Sözcükler: Gavin Bolton, drama, eğitimde drama, eğitimde tiyatro

\section{Gavin Bolton's Drama Approach in the Field of Creative Drama}

\begin{abstract}
In this study, drama, drama in education, theatre in education, dramatic activities, meaning and drama, objective and subjective meaning, aims and goals of drama, evaluation of drama lessons, the role of teacher during the process, drama legends, the elements of theatre in drama, the features of drama for meaning was investigated according to Gavin Bolton. And it was also given place to Gavin Bolton's biography.
\end{abstract}

Key words: Gavin Bolton, drama, drama in education, theatre in education

\section{Giriş}

Eğitim alanında 18. yüzyılda başlayan değişim ve gelişimlerle birlikte öğrencinin aktif olarak öğrenme sürecinde yer almaya başladığı sınıf ortamları oluşur. Bu yeni oluşan eğitim anlayışında öğrenenin duyguları, öznel yaşamı göz ardı edilmeden ele alınır. Özellikle İngiltere'de "eğitimde drama" kavramı öğrencinin aktif olarak eğitim sürecinde yer aldığı bir anlayışta ilerler. Bireyin yaratıcılığını keşfetmesinde ve kendisini ifade etmesinde en önemli yaklaşım olarak görülen eğitimde drama, Harriet Finlay Johnson, Caldwell Cook, Peter Slade, Brian Way, Dorothy Heathcote gibi önemli isimlerin çalışmaları ile eğitim sistemi içerisinde yerini alır.

Gavin Bolton, eğitimde drama alanına büyük katkıları olan bir araştırmacıdır. Bolton, alanda dil birliğini oluşturmak için drama alanının terminolojisi üzerinde çalışmalar yürütmüştür. Durham Üniversitesi’nde çalışmış olan Bolton, Dorothy Heathcote ile dramada uzmanlaşmaya gidecek yolları açan ve öğretmenlerin gelişimlerini hedefleyen eğitimler vermişlerdir. Dorothy Heathcote ve Gavin Bolton'ın yaptı̆̆ dramanın gelişiminde ve uzmanlık alanı olarak ilerlemesinde rol oynamıştır.

Drama alanında yer alan birçok kavramın ortak bir şemsiye altında toplanmasını sağlayan Bolton, Dorothy Heathcote ile ortak çalışmalar yürütmüş ve Heathcote'ın çalışmalarını kaleme alarak drama alanına kazandırmıştır. Bu nedenle Heathcote'ın drama anlayışını ayrıntılarıyla günümüze ulaştıran Bolton’dır.

Bilim Uzmanı, M.E.B, e-posta: asumanozcelik@yahoo.co.uk

2 Doç. Dr. Anadolu Üniversitesi, e-posta: alio@anadolu.edu.tr 
Bolton'ın çalışmalarının asıl hedefi, drama öğretmenlerine ya da katılımcılara daha derinlere inmeleri için olanaklar sunmaktır. Drama alanında Gavin Bolton isminin önemli olmasını sağlayan en büyük etken, drama terminolojisinin onun tarafından oluşturulmaya başlanmasıdır. Aynı zamanda akademik çalışmaları ile öğretmenlere uygulama örnekleri sunarak öğretmenlerin drama uygulamalarında nelere dikkat etmeleri gerektiğini anlaşılır bir dille alan yazına kazandırmıştır.

Bolton'ın çalışmaları ve onun uygulamaları, yaşadığı ve pek çok ülkede eğitimde drama alanının gelişmesine katkı sağlamıştır. Sözgelimi eğitimde drama alanının bağımsız bir alan olarak üniversite programlarında yer alması bu katkılardan birini oluşturur.

Türkiye'de eğitimde drama alanında Bolton'un drama yaklaşımlarına ilişkin çalışmalar çok azdır. Onun yaklaşımlarının Türkiye'de tanınması ve yaygınlık kazanması, eğitimde drama alanının gelişı̇i açısından da önemlidir. Türkiye'de yürütülen eğitimde drama çalışmalarının daha doğru anlaşılması, alandaki öncülerin görüşlerinin tam olarak tanınmasıyla doğru orantılıdır. Eğitimde drama alanında bir öncü olan Bolton üzerine Türkiye'de Sağlam (2006) ve Adıgüzel (2010) tarafından yapılmış çalışmaları ve çevirileri içeren birkaç araştırmanın dışında herhangi bir çalışmaya ulaşılamamıştır. $\mathrm{Bu}$ nedenle eğitimde drama, eğitimde tiyatro, anlamak için drama, dramada tiyatro ögeleri, dramada anlam, dramada öğretmenin rolü, dramada değerlendirme aşaması gibi kavramların ayrıntılı olarak ele alınması ve incelenmesi gerekliliği bu çalışmanın gerekçe ve kapsamını oluşturmaktadır.

\section{Yöntem}

$\mathrm{Bu}$ çalışma, var olan bir durumu var olduğu şekilde betimlemeyi amaçlayan tarama modelinde bir çalışmadır. Tarama araştırmalarında, geçmiş olaylara ilişkin olgu bulma, ilişki kurma ve yargılarda bulunabilme amacı ile kanıtların toplandırılması ve değerlendirilmesi önem kazanır (Karasar, 2002: 78). Tarama araştırmalarının amacı genellikle araştırma konusu ile ilgili var olan durumun fotoğrafını çekerek bir betimleme yapmaktır. Araştırma öncelikle Gavin Bolton'a ait kaynak taraması yapılarak yürütülmüş, daha sonra araştırma başlığıyla ilgili ulaşılabilen bütün yerli ve yabancı kaynakların taranması, incelenmesi ve yorumlanması ile tamamlanmıştır.

$\mathrm{Bu}$ çalışma sonucunda eğitimde drama tarihinde önemli bir yere sahip olan Gavin Bolton'a göre drama, eğitimde drama, eğitimde tiyatro, dramatik etkinlik, anlam ve drama, nesnel ve öznel anlam, dramanın amaç ve hedefleri, drama dersinin değerlendirilmesi, süreç içerisinde öğretmenin rolü, drama efsaneleri, dramada tiyatro ögeleri, anlam için dramanın özellikleri gibi kavramlar yerli ve yabancı alan yazın taranarak incelenmiştir.

Araştırmada Bolton'un öz yaşam öyküsüne, drama anlayışına, oluşturduğu terminolojiye yer verilmiştir. Gavin Bolton'ın yayınlarında ele aldığı dramatik etkinlik türleri, tiyatro ve drama, eğitimde drama ve eğitimde tiyatro, teatral ögelerin dramada kullanımı, dramada anlam, drama dersi için ön koşul, drama dersinin amaç/ hedefleri, drama dersinin değerlendirme aşaması, dramada öğretmen gibi konulara yer verildiği görülür.

\section{Bulgu ve Yorumlar}

Bolton, eğitimde dramanın amacının aklın gücünü geliştirmek olduğunu savunur. Böylece hayatı anlama gücü de geliştirilmiş olur. Ortak anlayış bilginin biçimlerini karşısına alır ve bu ders konularına "içeriden" yaklaşmanın titiz bir yoludur. Yığınlar biçiminde hazırlanmış bilgiler halinde anlatılan klasik ders anlayışından daha iyidir. Pedagojiye göre bu yaklaşım, öğrenen için geleneksel değildir ve öğrenen kendini rolün içinde göremez (Bolton, 1984, s.163). Eğitimde drama, bilgiye doğru bir yoldur; durumlara farklı açılardan bakma yolları açar. 
Dramada olan her şey bir şeyle ilgilidir. Beceri gelişimine odaklanmaktan daha çok olaylar, ilişkiler ve sorunların objektifinden insan olmanın ne anlama geldiğini keşfetmelerini sağlamak için kurgu ve rolleri kullanır. Süreçte keşfettikleri olaylar, sorunlar, ilişkiler, drama deneyiminin içeriğini temsil eder (Bolton, 2007, s.53).

Bolton (1985, s.154), dramanın kolektif bir kutlama, yaşama ve deneyimleme olduğunu savunur. Bu kolektif deneyimleme, bir grup öğrencinin veri girişi ve dönütleri ile güçlenir. Bolton, bir "efsane" olarak drama eğitimi çevresinde gelişen bazı kavramları açıklar:

Birinci efsane, "Drama yapmadır (eylemdir)."; ikinci efsane, "Drama gerçeklikten bir kaçıştır."; ikinci efsane, "Drama gerçeklikten bir kaçıştır."; üçüncü efsane, "Drama eğitimi, bireyin tek olarak; gelişimi ile ilgilidir."; dördüncü efsane, "Drama kişisel gelişimdir.”; beşinci efsane, "Drama anti-tiyatrodur.". Bolton'ın tartışmaya değer bulduğu diğer bir konuysa tiyatro ve drama ikilemidir. Bolton, tiyatro ve dramanın uzun uzun tanımlanması ve açıklanması yerine, bu kavramların katılımcıya nasıl bir deneyim yaşatacağı, eğitsel, sosyal konulardaki kişisel farklılıklarını keşfetmede nasıl etki edebileceği üzerine düşünülmesinin gerekli olduğunu vurgular. Ayrıca Bolton, eğitimde drama mı ya da eğitimde tiyatro mu tartışması yerine, eğitimde tiyatro ögelerinin drama sürecinde olup olmamasının tartışılması gerekliliğini belirtir. $\mathrm{O}$, drama ve tiyatro arasında ortak ögelerin bulunduğunu ve bu ögelerden yararlanılması gerektiğini savunur.

Bolton için drama dersinin amaçları da önemlidir. Dramanın bir salıncak gibi belirlenen amaçlar arasında gidip geldiğinden söz eder. Bolton, uygulanacak drama çalışmalarında iyi bir öğretmenin bu amaçlar arasında anlık olarak ileri geri gitmesi gerektiğini savunur. Sınıfın ve çalışmanın özelliklerine göre hangisine daha fazla önem vermek gerektiğini belirlemenin önemli olduğunu vurgular.

Amaçların belirlenmesinden ve drama dersinin uygulanmasından sonra yapılması gereken değerlendirmedir. Bolton, amaç ve hedeflerin nasıl değerlendirileceğini sorgular. Ancak bu sorudan önce neyin değerlendirilmesi gerektiğinin belirlenmesi gerektiğini savunur. Bolton için en önemli değerlendirme sorusu, katılımcıda bir anlam değişikliği olup olmadığıdır.

Dramada Bolton'ın ele aldığı bir başka öge ise öğretmenin rolüdür. Bolton, drama öğretmeni/liderinin katılımcının motivasyonunu amaca yönelik olarak sağlıklı bir biçimde yönlendirmesi gerektiğini belirtir, çünkü lider/öğretmen karşısında her zaman drama çalışmasına istekli bir topluluk bulamayabilir. Bazen de çocuklar konuyla ilgilenir ancak çekingen davranırlar ki bu durumda da öğretmen/lider devreye girmeli çocukların kendilerini rahat hissetmeleri için çalışmalı, bu yönde söz gelimi hemen bir oyun oynatarak çocukların üzerlerindeki gerilimi hafifletmelidir (Bolton, 1986, s.167).

Drama alanında ortak bir terminolojinin oluşmasını sağlayan Bolton, birçok yanı ile drama dersini ele almış ve yayınlarında bu görüşlerini alana kazandırmıştır. Drama dersi için önemli olan amaç ve hedefler, öğretmen, tiyatro ögeleri, değerlendirme aşaması, dramanın sanatsal yanı gibi drama öğretmenleri tarafından merak edilen, ancak bir türlü netleştirilemeyen sorulara yanıtlar vermiştir.

Bolton dramay1, "ipliklerde oluşan düğümleri çözme" olarak nitelendirir (Bolton, 2007, s.45). Drama, ipliklerin keşfedilmesi ve onların eğitsel bağlamda kullanılmasıdır. İplikleri çözerken çocukların yaşadığı deneyim süreci önemlidir. Ancak çocukların deneyimlerle hipnotize edilmesini istemez. Amacı, çocuğun drama sürecinde kendisine neler olduğunun ve bu süreçte kendi sorumluluklarının farkında olmasıdır. Bundan dolayı aslında çocuk bazı zamanlar kendisini dıştan izleme olanağı yakalar. Çocuğun buradaki amacı bir başkasına yaptıklarını beğendirmek değil, anlama ortamları ve firsatlarını sezgisel olarak tanımasıdır. Bu öz bilinç, kendini bilmeden çok farklıdır (Bolton, 1979, s.74). Drama bir metafordur. Onun anlamı ne var olan metinde ne de kurgusal olanda yer alır. Anlam bu ikisinin arasında kurulan diyalektikte yer alır (Bolton, 1979, s.127). Eğer kurgu ve gerçek arasında bir anlam oluşturulabilir ise amaca ulaşılacaktır. 
Bolton (1967, s.48)'a göre drama eğitimi; çocukların kurgusal bir bağlamda ilgili konuları, olayları keşfederek ve birbirleri ile ilişkilendirerek kendi yaşantıları ile ilgili anlam oluşturabilecekleri düzeye gelmelerini sağlayan bir öğrenme yolu ve sanat formudur. Bolton eğitimde drama anlayışını savunurken drama sürecinde katılımcıda bir anlayış, değer değişikliğinin olması gerekliliğini vurgular. O, eğitimde dramanın amacının aklın gücünü geliştirmek olduğunu savunur. Böylece hayatı anlama gücü de geliştirilmiş olur. Ortak anlayış, bilginin biçimlerini karşısına alır ve bu ders konularına "içeriden" yaklaşmanın titiz bir yoludur. Yığınlar biçiminde hazırlanmış bilgiler halinde anlatılan klasik ders anlayışından daha iyidir.

Bolton'un bu anlayışı, katılımcıları serbest bırakılmış ifadeden çok, katı ve zorlayıcı bir yapı içine girmeye zorladıkları yönünde eleştiriler alır. Bolton eleştirilere rağmen dramanın öğrenme ortamlarında katılımcıda anlayış değişikliği oluşturması gerektiğini görüşünü savunmaya devam eder. Seçme Yazılar (Selected Writings, 1986) kitabında Bolton, "yeniden değerlendirme" başlığı ile drama eğitimi çevresinde gelişen bazı kavramları açıklar.

Bolton'a göre birinci efsane "Drama yapmadır (eylemdir).". Bolton, birçok uygulayıcının dramayı etkinlik odaklı olarak gördüklerini ve bu hiçbir şey değilse "yapma (eylem)" olarak nitelendirilebilir görüşü ile bu efsanenin ortaya çıtı̆̆ını belirtmektedir. Kısmen doğru olan bu efsaneye eklenecek ögelerin varlığından söz eden Bolton, drama anlayışının doğasını bozduğunda ya da onun öğrenme potansiyelini göz ardı etmemize neden olduğunda dramanın "yapma” olmadığından söz eder.

İkinci efsane “Drama gerçeklikten bir kaçıştır.”. Drama oturumlarında kullanılan oyun, bazı eğitimciler tarafından çocuğun gerçek yaşamın acımasızlığından kendisini koruması için en doğal yer olarak nitelendirilir. Bolton ise kişinin kendisini kaybetmesinin değil kendisinde var olan, daha önceden edinilmiş anlamların ve bilgilerin açığa çıkarılması olarak nitelendirdiği drama sürecinde, gerçekliğe dıştan bir göz olarak bakmayı ve sağlamaya çalışmaktadır. Gerçek hayattan uzaklaşırken kurgunun içinde gerçeği yaşatmayı hedefler.

Üçüncü efsane "Drama eğitimi, bireyin tek olarak gelişimi ile ilgilidir.”. Bolton (1986, s.261) bu görüşün gerçekten göz ardı edilemeyeceğini, bireyin gelişiminin önemli ve değerli olduğunu belirtir. Ancak ona göre göz ardı edilen bazı ögeler vardır. Doğası gereği drama küme etkinliğidir ve bu süreçte katılımcılar bütün bireylerin sahip olduğu ortak özelliklerle bireysel farklılık olmadan sorgular, keşfeder, kutlar, yorumlar ya da düşünce belirtirler. Bu süreçte her bireyde oluşan anlam değişikliği farklı seviyelerdedir. Aynı olması zaten beklenemez. Ancak bütün katılımcıların ortak olarak paylaşabilecekleri somut bir eylemle bağlantılı etkinliklere yer verilmelidir.

Dördüncü efsane “Drama kişisel gelişimdir.”. Öğretmen için drama dersinde tematik içeriğin öğrenciler tarafından anlaşılması öncelikli kazanım olmalıdır. Diğer kazanımlar bu kazanımın edinilmesinden sonra gelir. Daha önce belirtilen ögelere tematik anlamdan sonra ulaş1lır. Fakat öğretmenin de öğrencinin de ilk önceliği “anlam” olmalıdır (Bolton, 1986, s.262).

Beşinci efsane “Drama anti-tiyatrodur.”. Bolton (1986, s.263) ise amacının hiç kimseyi belirli bir kutup etrafında toplamak olmadığını, sadece biçim ve yapı olarak tiyatro ve drama arasındaki ayrılık ve benzerlikleri göstermeye çalışmak olduğunu ifade eder. Drama ve tiyatro karşılaştırıldığında biçimsel değerlendirmeden sonra yapısal değerlendirme Bolton tarafından ele alınır. Bolton, ayrımları konuşmak yerine benzerliklerin ele alınması gerektiğini savunur. Ona göre tiyatro ve drama arasında yapı olarak benzerlikleri değerlendirmek daha önemlidir. Tiyatro ve drama arasındaki ortak noktalar ise odak, gerilim, zıtlık ve sembolleştirmedir. Bu ögeler anlamın elde edilmesi için dramada kullanılır. Tiyatronun temel ögelerini kullanmamız daha derin anlamlar elde etmemizi sağlar, görüşünü savunan Bolton'ın (1986, s.268) tek istediği şey, dramanın oyunculuk tekniklerinin eğitimi olarak görülmemesi ve sonuca odaklanılarak süreç içinde yaşanan derinlemesine çalışmanın göz ardı edilmemesidir. 


\section{Eğitimde Drama: Bir Sanat Gelişimi ya da Öğrenme Ortamı}

Dramayı bilgi edinmede yararlı bir araç olarak gören Bolton, drama dersinin hem eğitim hem de sanatın beklentilerini karşılayacak biçimde yapılandırıldığında, öğrenme/öğretme deneyiminin daha etkili olacağını belirtir. Yaşamdan alınan ve dramatik şimdi ve dramatik var olma (metaxis) yoluyla soyutlanarak mercek altına konan bir durumu irdelemek; soyutlanan durumu, o durumun hem evrensel yanını hem de altta yatan anlamlarını ortaya çıkaracak biçimde ele almak, dramanın estetik yaklaşımının temelini oluşturur.

Bolton, bir sanat formu olarak dramatik etkinliğin niteliğinin ne olduğunu incelemeye; dramatik etkinliği bir davranış biçimi olarak ele alıp, onu diğer davranış biçimlerinden farklı kılan özellikleri saptamakla başlamak gerektiğini belirtir. Bolton'a göre (1986, s.130) dramatik etkinlik, bulunulan ortamdaki eylem ve nesneleri kullanarak ortamdan bağımsızlaştırılmış bir anlam yaratmaktır. Fakat her dramatik etkinlik sanatsal değildir. Bolton, dramatik oyunun sanatsal bir form olabilmesi için üç önemli özellik göstermesi gerektiğini savunur (Tsiaras, s.3). Sanatsal etkinlik için gerekli bu üç nitelik; zaman algısı, anlamın niteliği ve duygunun niteliğidir. "Bir grup çocuğu oyun oynarken gördüğümüzde oyunlarını estetik olarak nitelendirebilir, ancak sanat olarak nitelendiremeyiz." diyen Bolton, zaman, anlam ve duygu niteliğinin eklenmesi ile oyunun sanatsal bir ifade kazanacağını belirtmektedir. Bu niteliklerin dramatik etkinliklere eklenmesi, öğrenme deneyimini destekler ve derinleştirir.

Dramanın bir sanat olup olmadığı ile ilgili uzun yıllardır süregelen tartışmaların oldukça yersiz olduğundan söz eden Bolton, drama uygulamalarında amaç ne olursa olsun (süreç ya da sonuç) dramatik bir yapının varlığı için temel tiyatro ögelerinin varlığının ve kullanımının reddedilemeyeceğini ifade etmektedir. Sanat ve drama arasında ortak noktalar olarak belirlenen gerilim, zıtlık ve sembolleştirme dramatik formun yapı taşlarıdır. İki farklı kutbun tartışmasının gereksizliği her ikisinin de tiyatronun ögelerini kullanmaları bakımından açıktır. Bolton (1999, s.179), gerilimin bir sorun, tehdit, şüphe, merak, mucize, istifa ve bunun gibi birçok şeyin olabileceğini belirtir. Zaman ise geçmiş ve geleceği taşıyan gerilimiyle, sanatsal biçimin zaman algısını oluşturur. Şimdiki zamanın özel bir halidir bu; dramatik şimdi. Bulunduğumuz anda durmayan, geçmişe ve geleceğe vaatlerinin ve sonuçlarının gerilimini taşıyan bir kavramdır. Bolton'a (1986, s.160) göre kurgu ile gerçek zaman arasında yaşananlar gerilimdir. Bolton, odak kavramını bir konunun ya da temanın parçalara ayrılması olarak nitelendirmektedir. Sürprizi ise şöyle açıklar; bu ögeye, sadece öğrenci gösteri amacı olmadan drama yapıyorsa yer verilmelidir. Bolton'ın tanımıyla çocuk kendisi için oynuyorsa sürpriz gereklidir. Çocuğun seyirci için hazırladığı oyundaysa amaç sadece bu sürprizi seyirciye hissettirebilmektir. Öğrenciler beklenmedik durumlar ile karşılaşarak drama içinde yer alırlar. Bolton bazen sürpriz durumlara yer verilmesinin yersiz olacağını bu nedenle başka ögelere yer verilmesi gerektiğini vurgular. Bu durumda bir zıtlık durumu olabilir. Son olarak Bolton'a göre sembolleştirme, katılımcı ya da izleyici için belirli anlamların belirli eylem ya da nesneler ile onaylanması sürecidir (Bolton, 1986, s.160).

\section{Drama ve Anlam}

Drama sürecinde öğretmenin ilgilendiği nokta çocuğun ne kadar iyi sahneleme yaptığı değil, çocuğun diğer çocuklarla sembolik etkileşim sürecinde anlamı bulmak için ne kadar iyi çalıştığıdır (Bolton, 1986, s.209). Ancak Bolton en büyük sorunun hem katılımcı hem de öğretmen tarafından dramada yaşanan deneyimlerin ve bunların anlamlarının göz ardı edilmesi ile oluştuğunu düşünmektedir. Öğretmen ve öğrenci tarafından edinilen anlamın aynı olup olmaması, uygulanan dramanın tipine (A tipi, B tipi, C tipi, D tipi) bağlıdır. Bu nedenle Bolton, dramada anlamı tartışmak yerine, dramada anlamın seviyelerini gruplandırmayı tercih etmiştir. 
Bolton dramanın en somut sanatlardan biri olduğunu savunmaktadır. Çünkü ona göre anlam iki somut olayın birbiri ile etkileşiminden oluşmaktadır: katılımcı tarafindan gerçek zaman ve yerin kullanılması, kurgusal süreçte varsayılan zaman ve yerin kullanılması. Örneğin çocuğun bir çubuğu alıp bacaklarını açarak üstünde durması gerçek bir durumdur. Kurgusal olan ise çocuğun o çubuğu at olarak düşünüp, ata biniyormuş gibi davranmasıdır (Bolton, 1986, s.224). Bolton'nın bu örneğinde de olduğu gibi anlam öncelikle iç ve dış eylemin etkileşimi ile ortaya çıkmakta daha sonra ise öğrenmeyi tetiklemektedir.

Anlamı ise "öznel” ve "nesnel” anlam olarak ikiye ayırır. Bolton, D tipi drama (anlamak için drama) olarak nitelendirdiği çalışma türünde öncelikli hedefin "öznel anlam boyutunda öğrenme” olduğunu belirtmektedir. Öznel anlamda değişikliğin ve öğrenmenin gerçekleşebilmesi sadece nesnel anlamın oluşmasından sonra ulaşılabilecek bir noktadır. Öznel anlamın kalitesi ise hem oyunda hem de dramada oluşturulan üç farklı anlam boyutu ile ilgilidir.

1. Toplum tutumunun nesnel anlamla uyumu

2. Kişisel hislerin nesnel anlama uygunluğu

3. Kişisel hislerin nesnel anlam ile ilgisizliği (Bolton, 1979, s.33).

Seviye 3: Çocuk hem oyun sürecinde hem de drama sürecinde bazı uygunsuz, ilgisiz davranışlar sergileyebilir. Süreçle ilgili olmayan tutum ve davranışlarda bulunma söz konusudur.

Seviye 2: Bolton'nın bu seviyede açıkladığı duygu ve tutumlar genelde ham duygu olarak nitelendirilen, durumlar karşısında ilk akla gelenlerdir. Çocuk, drama ya da oyun sürecinde gördükleri karşısında hissettiklerini aklına ilk gelen biçimi ile ifade eder.

Seviye 1: Bu aşamadaki etkinlikler -mış gibi oyunlarında ilgilerini çeken konunun ne olduğunu ayırt eden sınıfa bağlıdır.

Öznel anlam bu üç seviye arasındaki etkileşime bağlıdır. Tecrübelerden dramaya doğru ilerleme ortak seviye olan 1. seviyede duyguların özel kalitesi, paylaşımı, kişisel seviyeden üstünlüğü, nesnel anlam ile uyumu ile tanımlanır.

Katılımcının öncelikle nesnel daha sonra öznel anlayış değişikliğine sahip olabilmeleri için öğretmen tarafından öncelikle uygun ortamın sağlanması ve drama oturumunun bu doğrultuda planlanması gerekmektedir.

Bolton'ın üzerinde durduğu "anlam için drama” türünde amaç öğrenmenin gerçekleşmesidir. Bolton dramada öğrenmeyi "değerlerde hissedilen değişiklik" olarak ifade etmektedir. Hissedilen ile ifade edilen öge ise diğer hiçbir sanat türünde olmayan belirli bir zaman ve yerde, süreç içerisinde yaşamadır. Ancak bu sıradan bir yaşam değil, kurgulanan ve tasarlanan bir süreçtir (Bolton, 1986, s.215).

\section{Dramatik Etkinlikler}

Bolton, dramatik etkinliği diğer etkinliklerden ayıran özelliğin; anlamın, eylem ve nesneden ayrılması olduğunu belirtir. Bolton dramatik etkinlikler ile bilişsel gelişimin önemini vurgulamaktadır. Bilişsel gelişim ile çocuğun düşünsel dünyasının etkilenmesi, değiştirilmesi, yeni düşünce ve kavramların o dünyaya eklenmesi ya da var olanların değiştirilmesi ifade edilir. Böylece çocuğun dünyaya bakma biçimi gelişecek, değişecektir. Ancak Bolton, çoğu drama öğretmeninin okullarda temel drama deneyimini/yaşantısını bu amaçlardan çok farklı olarak üç biçimde uyguladıklarını saptadığını belirtmektedir. Bu kümelemeler konuşma, doğaçlama ya da davranışların gruplandırılması değildir. Gruplamalar drama oturumlarının genel niteliklerine göre yapılmıştır. Drama yaşantılarında sadece bunların olduğunu düşünen kişinin büyük bir yanlışa düşeceğini belirten Bolton, bu uygulama biçimlerini örneklerle açıklamaktadır. Bolton’nın gözlemlediği bu üç ana başlık şunlardır: 
- A tipi: Egzersiz

- B tipi: Dramatik oynama/ Oyun Kurma

- C tipi: Tiyatro

İlk gurup olan A tipi alıştırmada Bolton drama öğretimi esnasında beş çeşit egzersiz gözlemlediğini belirtmiştir. Bolton, her biri farklı amaçlarla uygulanan bu alıştırmaları şöyle kümelendirmiştir:

1. Doğrudan Deneyimleme: Çocuğun gerçek ortamda belirtilen durumu yaşaması ve deneyimlemesini sağlayan alıştırma türüdür.

2. Dramatik Beceri Uygulaması: Bu tür alıştırmalarda sadece çağrışımlar vardır. Hatırlatmalar yapılarak gerçekte olmayan durumu deneyimlemeleri sağlanır.

3. Drama Alıştırması: Öğrencilere belirli durumlar verilir, bu durumları canlandırmaları ve doğaçlamalar1 istenir.

4. Oyunlar: Belirli bir amaca ulaşmak için seçilen etkinlik türü olarak belirtilen oyunlar şöyle örneklendirilmiştir.

- Etkin: "Çamurdaki sopa"

- Konsantrasyon: "Vizilt1"

5. Diğer Sanat Dalları: Resim, müzik, edebiyat gibi sanat dallarından da yararlanarak drama etkinliğinin sürdürülmesidir.

Bolton bu örnekleri vermesinin hemen ardından bunların tek başına yeterli olmadıklarını ifade eder. Hatta Bolton, "Bunları derslerinde uygulayan ögretmenler, drama yaptıklarını sanırlar ancak bunlar alt seviyede olan deneyimlemelerin alıştırmalarıdır" diye ifade etmektedir.

İkinci gurup ise B Tipi: Dramatik Oynama. Bolton dramatik oynamanın okulda gerçekleşen, öğretmen ve öğrenci tarafından drama olarak nitelendirilen bir etkinlik olduğundan bahseder. Ona göre bu etkinlikler drama değildir (Bolton, 1979, s.7).

Son olarak ise 3. Grup C tipi: Tiyatro. Resmi ya da gayri resmi sahnelemenin olduğu bu tür, seyirci ile paylaşımı kapsar. Drama çalışmasının amacı bir gösteri hazırlayabilmektir.

Bolton, üç başlık altında verdiği gözlemlerine dayalı drama deneyimlemelerinin tek başına drama anlamına gelmediğinden söz etmektedir. Öğretmenler bu üç kümede bulunan drama deneyimlemelerinden herhangi birini ya da üçünün ortak yönlerini kullanabilirler. Ancak ona göre drama bu üç türden de yararlanan, farklı bir tip olarak nitelendirdiği D Tipi dramadır. Bolton bu tür drama etkinliğini “Anlamak için Drama” olarak isimlendirmektedir. Bolton'nın karışım olarak nitelendirdiği A (Alıştırma), B (Dramatik Oynama), C tipi (Tiyatro) dramanın her üçünün de içinde var olduğu bu tip drama, D tipi drama etkinliğidir. İçinde oyun, dramatik oynama ve kimi zaman tiyatroyu da barındıran bu türde anlama çok önemlidir. Ayrıca katılımcının düşünce değişikliği Bolton'nın odaklandığı noktadır.

Ancak hedeflenen değişiklik karakter değişikliği değil, hislerin bulunduğu bilişsel hareket ve değerlendirme değişimidir (Bolton, 1979, s.41). Bu nedenle Bolton'a göre anlayış değişikliğinin gerçekleşebilmesi ve öğrenmenin oluşabilmesi dört aşamada gerçekleşir. Birinci ve ilk aşama yapay drama olarak adlandırdığ aşamadır. Bolton'nın yapay drama olarak nitelendirdiği bu aşama, katılımcının etkin olarak anlama sürecine geçemediği, öğrenme için üreticiliği olmayan hazırlık aşamasıdır. İkinci aşama ise Bolton tarafından destek aşaması olarak isimlendirilmiştir. Yapay drama olarak isimlendirilen üretimin olmadığı süreçten sonra bu aşamada katılımcı bildiklerini bilinçsizce tekrarlayarak bir sonraki aşamada ne olacağını düşünerek drama çalışmasını 
sürdürür. Birinci aşamada bir gelişme olabilir, ancak bu gelişmenin eğitsel yanı biraz şüphelidir (Bolton, 1979, s.45). Üçüncü aşama arıtma aşamasıdır. Bolton'a göre bu aşama bilinenlerin bilinçli bir biçimde ayırt edildiği süreçtir. Öğretmenler genelde öğrencileri küçük kümelere ayırarak belirli bir konu verirler. Bu kümeler bu konu ile ilgili tartışır ve çalışırlar. Sonuç ise genellikle tartışılan, çalışılan konunun gösterisi şeklindedir. Son ve dördüncü aşama ise değişiklik aşamasıdır. Drama sürecinde destek ve arıtmadan sonraki aşama değişikliktir. Değişiklik, anlayış değişikliği olarak açıklanır. Bolton (1979, s.45), "Çalışma deneyimsel duygu düzeyinde gerçekleşirse anlayış değişikliği oluşur.” demektedir.

\section{Tipi Dramanın (Anlamak İçin Dramanın) Özellikleri}

Bolton tarafından aşamaları ile belirtilen öğrenmenin gerçekleşmesinin hedeflendiği D tipi drama, A (Alıştırma), B (Dramatik Oynama) ve C tipi (Tiyatro) dramadan amaçları bakımından ayrılmaktadır. D tipi dramada diğerlerinden farklı olarak beklenen, katılımcının süreci yaşamasıdır (living through). Bu kavram ile ifade edilmek istenilen, katılımcının kurgusal dünyada gerçek dünyayı yaşamasını sağlamaktır. Katılımcının içselleştirme süreci önemlidir.

Süreci yaşamak (living through), Bolton tarafindan iki boyutlu olarak açıklanmaktadır. Birinci boyutu, yaşanılan deneyimlerde "Ben yaptığım için oldu." hissidir. İkinci boyutu ise "Bu bana oluyor. (Beni etkiliyor.)" hissidir. Belirtilen durumlardan birincisinde katılımc1 kendisini aktif, ikincisinde ise pasif olarak nitelendirmektedir. D tipi drama (anlamak için drama) uygulayan hiçbir drama öğretmeni, çocuğun "Bu bana oluyor.” demesine izin vermemelidir. Çünkü bu tür dramada Bolton’nın istediği şey, katılımcının aktif olarak süreci yaşaması ve bu süreci deneyimlemesidir.

Bolton, D tipi dramada görünen davranışın yani dış eylemlerin bize çocuğun iç dünyası hakkında bilgi verdiğini tiyatro terimlerinden yola çıkarak açıklamaktadır. İç eylemi ise kişinin somut verilerden yola çıkarak soyuta ulaşması olarak açıklamaktadır. Çocuğun nesneler ya da kişilere karşı iç dünyasında taşıdığı anlamın dışa vurumu iç eylemdir. Dış dünyaya karşı kişide var olan tutum ve hisler kişinin eylemlerine yansır.

Bolton D tipi dramada şu özelliklerin irdelenmesi gerektiğini savunur. Bunlar; tür, amaç, içerik, drama dersi için ön koşul, drama dersinin amaç ve hedefleridir. Bolton bu unsurların özenle ele alınması gerekliliğini savunur.

Bolton, okullarda yapılan drama çalışmalarının üç çeşit (tür) olduğu sonucuna varıldığını belirtmektedir. Birincisi süreç odakl1- öğrenci merkezli, ikincisi gösteri odakl1- tiyatrodan kaynaklı, üçüncüsü ise beceri odaklı drama uygulamalarıdır. Süreç odaklı çalışmanın kendiliğinden, anlık ve deneyimleri içerdiği; gösteri odaklı çalışmaların ise iletilebilir, tekrarlanabilir, deneyimlerin gösterilebilir olduğu; beceri odaklı çalışmaların ise yakın hedefleri içeren etkinliklerden (örneğin güven çalışmaları ya da oyunculuk egzersizleri) oluştuğu gözlenmiştir (Bolton, 1986, s.181).

Drama dersinin amaçlarını açıklarken öğretmeni bu durumu yöneten olarak ifade eder. Drama çalışmalarında öğretmenin hedeflediği birçok kazanım sıralanabilir. Bu sıralama, durumlara göre farklılık gösterebilir ve yer değiştirebilir. Eğer drama bir okul programının içerisinde uygulanıyor ise öncelikle amaç, anlayış değişikliği oluşturmaktır (Bolton, 1986, s.184).

Eğitimde drama uygulamalarında konu seçimi ve içeriğin en kolay mesele olduğunu belirten Bolton, herhangi bir konunun drama uygulamasında kullanılabileceğini belirtir. Öğretmenin konu seçimi, öğrencilerin gereksinimlerine ve sahip oldukları hazır bulunuşluk düzeylerine göre belirlenebilir.

Bolton, tema seçiminin drama çalışmasından önce gerekli olan en önemli ögelerinden birisi olduğunu vurgular. Süreç odaklı çalışacak bir öğretmen için seçilen konunun süreç içerisinde gerçekten bir anlam 
değişikliğine yol açacak düzeyde olması gerekmektedir. Bolton (1986, s.193)'ın genelde ele aldığı konular, değerler ve ahlaki sorunlardır. Kurgunun içinde gerçek dünyayı deneyimleyen katılımcının anlam değişikliği ile öğrenme alanında yer almasını amaçlar.

\section{Drama Dersinin Amaç ve Hedefleri}

Bolton (1984) “İngiltere’de Drama Eğitiminin Tarihçesi” adlı makalesinde, tarih boyunca dramanın farklı amaçlarla kullanıldığından söz eder. Metin odaklı drama çalışmalarının başlamasından, öğrenci odaklı çalışmaların var olmasını sağlayan Peter Slade'e kadar ve içerik odaklı çalışmalar yapan Dorothy Heathcote'dan beceri odaklı çalışmalara kadar öğretmenlerin politik baskılar ile farklı görüşlerle karşı karşıya kaldığından söz eden Bolton, politik baskılar ile öğretmenlerin farklı görüşlerle karşı karşıya geldiğinden söz eden Bolton, dramanın bir salıncak gibi bu amaçlar arasında gidip geldiğinden bahseder. Yaptığı araştırmalar ile dramanın ilerlemesini sağlayan öncüler tarafından göz önünde bulundurulan amaçlarını dört ana başlıkta toplar. Bu dört başlı̆̆ın genel olarak drama çalışmalarında öğretmenler tarafından amaç olarak belirlendiğini ifade eder (Davis, 2010, s.45).

1. İçeriğin vurgulandiğı çalışmaya yer verme,

2. Kişisel gelişim için dramayı düzenleme,

3. Dramayı sosyal gelişim aracı olarak esas görme,

4. Öncelikli olarak dramatik sanat formunun öğretimini savunma.

\section{Drama Dersinin Değerlendirilmesi}

Değerlendirme, öğretmenin drama yoluyla öğrencinin öğrenmesini ve gelişimini gözlemlemesine yardımcı olur. Aynı zamanda her bir öğrencinin gereksinimlerini belirleyerek öğretmene etkili bir öğrenme için drama içeriğini oluşturma ve programı uyarlama firsatı sağlar. Eğer bu biçimde kullanılırsa drama çocukların geleceğini biçimlendirici bir role sahiptir.

Bolton bu aşamada amaç ve hedeflerin nasıl değerlendirileceğini sorgular. Ancak bu sorudan önce neyin değerlendirilmesi gerektiğinin belirlenmesi gerektiğini savunur. Bu nedenle dört çeşit değerlendirme olduğunu belirtir.

1. Ö̆̆retmenin dĕgerlendirilmesi,

2. İşin dĕ̌gerlendirilmesi,

3. Ö̆̆grenci gelişsiminin dĕgerlendirilmesi,

4. Başarının değerlendirilmesi (Bolton, 1979, s.132).

Drama sürecini planlayan ve yönlendiren drama öğretmeninin değerlendirilmesiyle başlayan Bolton, değerlendirme aşamasında öğretmene kendisi tarafından ya da başka bir gözlemci tarafından sorular sorulması gerektiğini belirtir.

Drama sürecinin sonunda bütünün değerlendirilmesinde önemli olan nokta, hangi tür dramanın uygulandığı ve ne amaçla drama uygulaması yapıldığıdır. Ölçülecek iş, değerlendirmeyi farklılaştıracaktır. Örneğin eğer becerilerde gelişmeyi amaçlayan bir drama çalışması yapılıyorsa değerlendirilmesi gereken iş becerilerdir. Ancak öğretmen tiyatro bilgisinin arttırılmasını hedefliyorsa değerlendirme yapılacak nokta, tiyatro becerilerinin elde edilip edilmediğidir.

Öğretmen, süreç içerisinde bilişsel/duyusal açıdan öğrenci gelişimini çok kolaylıkla ayırt edebilir. Öğrenciyi canlandırdığı roller içerisinde gözlemleyebilir. Çünkü çocuk kendisini rol içerisinde yansıtacaktır. Diğer bir ipucu ise deneyimlerinden elde ettikleriyle genelleştirmeler yapar ya da buna paralel davranışlar gösterir. Deneyimlerini diğer sanat alanları ile bağlantılı olarak yansıtabilir. 
Başarının değerlendirilmesinde ise drama öğretmeni, planladığı drama çalışmasının sonunda bir gösteri hazırlamamış olsa bile mutlaka oluşturulan bir ürün vardır. Dorothy Heathcote bunu "yansıma" olarak nitelendirir. Bolton ise nasıl isimlendirilirse isimlendirilsin mutlaka sonunda bir ürün olduğunu savunmaktadır. Öğrenci gelişiminin değerlendirilmesi için sıralanan sorular bir merdivense, basamakların en son noktasına ulaşmak ya da birkaç basamak bile olsa bulunulan yerden uzaklaşmak, drama uygulaması sonunda ulaşılan başarı olarak tanımlanır (Bolton, 1979, s.137).

\section{Drama Dersinde Öğretmenin Rolü}

Drama sınıfında öğretmenin rolünün gerçekte ne olduğu uzun yıllar tartışılmış ve çeşitli varsayımlarda bulunulmuştur. Çağın değişen eğitim yönelimlerine göre farklılık gösteren öğretmen rolü, drama dersini yapan öğretmenleri de etkiler. Bolton (1986, s.243) eğitimcileri uzun yıllar meşgul eden drama öğretmeninin rolünün, öğretmenin baskın olduğu geleneksel ve davranış̧̧ı sınıflarla romantik/ gelişimsel/ insancıl sınıf ortamlarının var olduğu öğrenci merkezli eğitim arasında gidip geldiğini belirtir. Bolton, drama öğretmenini "katılımcıya yoldaşlık yapan bir sanatçı" olarak tanımlar ve bu durumu iki biçimde açıklar: a) sanatçı olarak öğretmen- drama içinde çalışan, b) sanatçı olarak öğretmen- drama dışında çalışan.

Bolton, dramanın içinde ya da dışında da çalışsa drama sürecinde yer alan öğretmenin öncelikle esnek bir düşünce yapısına sahip olması gerektiğini ve bunu da öğrencileri ile paylaşarak onların becerilerini eğitmeleri gerektiğini savunur. Öğretmen kadar öğrencilerin de drama sürecinde nerede sınıflandırma yapacaklarını, duygularını yansıtacaklarını, evrenseli bulacaklarını, benzerlik arayacaklarını, ayrı anlamlar taşıyan eylemleri ne zaman irdeleyeceklerini bilmeleri gerekliliğini belirtir. Bolton, öğrencilerin düşünce geçişlerini de birbirleri ile paylaşmayı öğrenmeleri gerektiğini vurgular (Bolton, 1979, s.146).

Bolton, drama öğretmeni/liderinin katılımcının motivasyonunu amaca yönelik olarak sağlıklı bir biçimde yönlendirmesi gerektiğini belirtir, çünkü lider/öğretmen karşısında her zaman drama çalışmasına istekli bir topluluk bulamayabilir. Bazen de çocuklar konuyla ilgilenir ancak çekingen davranırlar ki bu durumda da öğretmen/lider devreye girmeli, çocukların kendilerini rahat hissetmeleri için çalışmalı, bu yönde söz gelimi hemen bir oyun oynatarak çocukların üzerlerindeki gerilimi hafifletmelidir (Bolton, 1986, s.167).

Bolton’a göre drama öğretmeni farklı özelliklere sahip olabilir. Ancak aşağıdaki koşulları kesinlikle taşıması gerekir:

- Öğretmen sınıf içerisinde çocukların duygularını, heveslerini, ilgilerini açıkça ortaya koyabilecekleri karşılıklı güven duygusu oluşturmalı,

- Öğretmen, öğrencileri drama çalışması sürecinde hangi tipi nasıl canlandırdıklarını çok dikkatli gözlemlemeli,

- Öğretmen, çocukların eğitsel ihtiyaçlarına göre yönergeler vermeli.

Yukarıda belirtilen özelliklerin yanı sıra öğretmen, "sınıfına ulaşabilmelidir” (Davis, Lawrence, 1986, s.11). 


\section{Kaynakça}

Adıgüzel, Ö. (2010). Eğitimde Yaratıcı Drama. Naturel Yayınevi, Ankara.

Allern, T. H. (2008). A comparative analysis of the relationship between dramaturgy and epistemology in the praxis of Gavin Bolton and Dorothy Heathcote. Research in Drama Education: The Journal of Applied Theatre and Performance. Vol. 13(3), 321-335. Routledge, UK.

Bailin, S. (2001). In the Spaces between the Words: Play Production as an Interpretive Enterprise. Journal of Aesthetic Education, Vol. 35(2), (Summer), pp. 67-75. University of Illinois Press, USA.

Bailin, S. (1993). Drama as Experience: A Critical View. Canadian Journal of Education, Vol. 18(2), (Summer), pp. $95-$ 105. Canadian Society for the Study of Education.

Bolton, G. (1979). Towards a Theory of Drama in Education. Longman Group Ltd., London.

Bolton, G. (1984). Drama as Education: an argument for placing drama at the cetnre of the curriculum. Longman, London.

Bolton, G. (1985). Changes in Thinking about Drama. Theory into Practice, 24(3), 151-157. Educating through Drama (Summer). Taylor \& Francis Ltd.

Bolton, G. (1986). Selected Writings of Gavin Bolton. (Eds.:D. Davis and C. Lawrence). Longman Group Ltd., New York.

Bolton, G. (1992). New Perspectives on Classroom Drama. Herts: Simon and Shuster Education, London.

Bolton, G. (1993). Voices for Change. (Eds. Chris Lawrence). National Drama, Newcastle Upon Tyne.

Bolton, G. (1995). Drama for Learning: Dorothy Heathcote's Mantle of the Expert Approach to Education. (co-author with Heathcote, D). Heinemann, N. J.

Bolton, G. (1998). Acting in Classroom Drama: A Critical Analysis, (co-author with Davis, D). David, Trentham Books.

Bolton, G. (1999). The Dramatic Difference: Drama in the Preschool and Kindergarten Classroom. Portsmouth, New Hampshire: Heinemann.

Bolton, G. (1999). So You Want to Use Role Play? (co-author with Heathcote, D) Trentham Books, UK.

Bolton, G. (2003). Dorothy Heathcote's Story: The Biography of a Remarkable Drama Teacher. Trentham Books, UK and USA.

Bolton, G. (2007). A History of Drama Education: A Search for Substance. (Ed. L. Bresler). International Handbook of Research in Arts Education (pp. 45-61). New York: Springer.

Bolton, G. (2010). Essential Writings. (Eds. David Davis). Trentham Books, UK.

Cramer, N. V. (2003). Literacy as a Performing Art: A Phenomenological Study of Oral Dramatic Reading. A Dissertation Submitted to the Gratuate Faculty of the Louisiana State University and Agricultural and Mechanical College in partial fulfillment of the requirements for the degree of Doctor of Philosophy in The Department of Curriculum and Instruction. Louisiana State University, USA.

Davis D.\& Lawrence, C. (1986). Selected Writings. (Ed. Gavin Bolton). Longman, Hong Kong.

Dönmez, B., Bayhan, P., Artan, İ. (2000). Engelli Çocuğa Sahip Ailelerin Beklentileri ve Endişe Duydukları Konuların İncelenmesi. Sosyal Hizmetler Dergisi, 1(11), 16-23. Ankara.

Jardine, L. (1995). Reading Gavin Bolton: A Biography for Education. A Thesis Submitted in Partial Fulfilment of The Requirements for the Degree of Doctor of Philosophy. The University of British Colombia. Vancouver, Canada.

Mimick, K. C. (2010). Drama Education and the Standards- based Education Movement: Impacts and Implications within British Columbia. A Dissertation Submitted in Partial Fulfillment of the Requirements of the Degree of Doctor of Philosophy in the Department of Curriculum and Instruction. University of Victoria, Canada.

National Curriculum Council (1990) The Arts 5- 16. Oliver and Boyd, York.

Njewele, D. C. (2008). An Opportunity to Introduce Drama in Education: A Case Study of Children's Theatre Project. University of the Witwatersrand, Johannesburg.

O'Farrell, L. (1998). Theatre as Educatıon: A Distinctively Canadıan Approach to Secondary School Drama. Theatre Research in Canada. Vol. 19(2), Canada. 
O'Sullivan, C. (2007) Defining our Practice in Drama in Education. In: 'Talkin' 'Bout My Generation': Archäologie der Theaterpädagogik II - The History of Theatre Pedagogy. (Ed: Marianne Streisand, Nadine Giese, Tom Kraus and Bernd Ruping). Schibri-Verlag, Berlin. pp.84-97.

Polisini, K. J. (1989). The Creative Drama Book:Three Approaches. Anchorage Press, New Orleans.

Rasmussen, B. (2008). Beyond imitation and representation: extended comprehension of mimesis in drama education. Research in Drama Education: The Journal of Applied Theatre and Performance. 13(3). 307- 319. Routledge, UK.

Sağlam, T. (2004). Dramatik Eğitim: Amaç mı? Araç mı?. Ankara Üniversitesi Dil ve Tarih- Coğrafya Fakültesi Tiyatro Bölümü Tiyatro Araştırmaları Dergisi, 17, ISSN: 1300-1523, s. 1-18.

Sağlam, T. (2006). Gavin Bolton Drama, Sanat, Öğrenme. Yaratıcı Drama Dergisi. 1(2), 57-66, Ankara.

Schonmann, S. (2005). "Master" versus "Servant": Contradictions in Drama and Theatre Education. Journal of Aesthetic Education, Vol. 39(4), Special Issue: Aesthetics in Drama and Theatre Education (Winter), pp. 31-39. University of Illinois Press, USA.

Spolin, V. (1963). Improvisation for The Theater. Northwestern University Pres, USA.

Taylor, P. (2003). The Drama Classroom: Action, Reflection, Transformation. RoutledgeFalmer, USA.

Urian, D. (2000). Drama in education: From theory to "study cases". Contemporary Theatre Review, 10(2), 1- 9. Harwood Academic Publishers, Malaysia.

Verriour, P. (1985). Face to Face: Negotiating Meaning through Drama. Theory into Practice. 24(3). Educating through Drama (Summer), pp.181-186. Taylor \& Francis Ltd.

Wagner, B. J. (1976). Dorothy Heathcote: Drama as a Learning Medium. National Education Association, Washington. 
EK: Gavin Bolton Biografisi

Gavin Bolton, hayatının önemli tarihlerini içeren biografiyi kendisi derlemiştir. Ona göre, bu tarihler yaşamında önemli dönüm noktalarıdır (Jardine, 1995, s.173-175).

\section{Gavin Bolton (1927- ...)}

1927- 13 Şubat tarihinde Gavin'ın doğumu.

1932-38 Gavin'ın ilkokul eğitimi.

1936 Diksiyon ve piyano eğitimine başlaması, düzenli olarak sınıf geçme sınavlarına girer. Ne yazık ki piyano dersini bırakır ve "Konuşma ve Drama" dersine başlar.

1938 Noel korosunda Tiny Tim olarak ilk sahne deneyimini yaşar.

1938-1943 Crewe Gramer okuluna başlar.

1943-46 İngiliz demiryollarında 'İşler ve Maliyet' bölümünde stajyer muhasebeci olarak ilk işi.

1944 Maliyet ve muhasebe işlerinde ilk sınavı.

1946 Öğretmenliğe geçiş (vasıfsız) "Körler ve Sağırlar Okulu”.

1948-50 Öğretmen olarak nitelik kazanması; Sheffield City Training College, University of Sheffield Institute, İngilizcede uzmanlaşması ve Ortaokulda uzmanlaşır.

1950-52 İlk görev yeri- Adelaide Street İlköğretim okulu, yönetim; aydın bir okul müdürü olan Geoff Durber ile çalışır.

1951 Temmuz ayında Gavin ve Cynthia evlenirler. Evliliklerinin ilk yılında ailesinin evinin iki odasında yaşarlar.

1951 Music ve Drama Kraliyet akademisinden 'Konuşma ve Drama' uzmanı olarak mezun olur.

1951-61 Her yaz tiyatro ile ilgili yaz okullarına katılır (sadece Peter Slade tarafından yürütülen 'Child Drama' başlıklı iki atölye hariç).

1952-59 Stratford ve Coventry yakınlarında Nuneaton, Warwickshire' da yaşamaya başlar ( 1957 yılında Coventry'de Belgrat Tiyatrosu açıldı). 1957 Arbury Ortaokulunda çalışmaya başlar ve İngilizce Başkanlığına terfi edilir.

1953 İlk evini satın alır.

İlk defa ders dışı olarak yapılan Gençlik Tiyatrosuna başlar.

Nuneaton Öğretmenleri Drama Topluluğunu kurar.

Peter Slade'in kursuna ilk defa katılır.

1956 Tiyatroda yönetmenlik ile ilgili olan İngiliz Drama Grubu (League) kursuna katılmak için görevlendirilir.

1957 Oğlu Andrew doğar.

1958 Peter Slade Birmingham'da Rea Sokağı merkezinde bulunan çalışmasına katılması için Gavin'ın Gençlik Tiyatrosu grubunu davet eder.

1959 Annesi vefat eder. 
1959-62 Lancashire, Preston'a taşınır ve Fishwick Ortaokulunda müdür yardımcılığına başlar.

Preston Öğretmenleri Drama Grubunu oluşturur ve Brian Way’in de katıldığı birçok hafta sonu çalışmaları düzenler.

Salford Üniversitesinde yönetmenlikle ilgili kurslara katılır ve ADB’yi kazanır (Associate of Drama Board).

1962-64 Okullara drama danışmanı olarak Durham'a taşınır.

1963 Babas1 vefat eder.

1964 Durham Üniversitesi, Eğitim Enstitüsüne Eğitimde Drama Bölümüne okutman olarak görevlendirilir. Öğretmenlerin drama alanında yetiştirilmesini amaçlayan bölümden sorumludur. Sonra kıdemli öğretim görevlisi ve 1985 y1lında ise doçent olur.

1967 Yurt dışında ilk öğretmenlik deneyimi güney Afrika'da olan Lesotho'dadır.

1968 Durham Üniversitesi master derecesi vermeye karar verir (MA).

1969 John ve Juliana Saxton'nın daveti ile Kanada’ya (Eğitim Fakültesi Toronto Üniversitesi) ilk ziyareti.

1966-72 Üniversite Drama Topluluğu başkanlığını yürütür.

1964 İlk makalesini yayınlar.

1969 Uzun yıllar arkadaşı, akıl hocası ve danışmanı olan Nora Morgan’a adadığı ilk kitabını yayınlar.

1976 Oğlu, Andrew müzik eğitimine Manchester'da Kuzey Kraliyet Kolejinde başlar. Andrew 1981 yılında evlenir ve iki çocuğu olur.

1987 Durham Üniversitesinden tam gün çalışma sürecinden emekli olur.

1988-89 Kanada'nın akademik yılı için Victoria Üniversitesinde profesörleri ziyaret eder.

1990 Laurine Jardine'nin de katıldığ İngiliz Colombia Üniversitesinde lisansüstü öğrencilerin yaz eğitimini verir.

1995 Öğretmenliğe veda! Ancak makale yazmaya devam eder. 